\title{
Investigation of oxygen scavengers influence on cooked sausages stability
}

\author{
Anatoliy Ukrainets, Vasyl Pasichniy, \\ Andrii Marynin, Yulia Zheludenko
}

\section{National University of Food Technologies, Kyiv, Ukraine}

Keywords:

Sausage

Stability

Oxygen scavengers

Storage

\section{Article history: \\ Received 15.05.2019 \\ Received in revised \\ form 16.10.2019 \\ Accepted 28.11.2019}

\section{Corresponding author:}

Vasyl Pasichniy

E-mail:

pasww1@ukr.net

DOI: $10.24263 / 2304-$

974X-2019-8-4-8

\section{Abstract}

Introduction. The effect of packing ukrainian and chinese oxygen scavengers on microbiological stability and oxidation stability of a cooked sausages during storage was investigated.

Materials and methods. Cooked sausages packing with different oxygen scavengers were examined. Microbiological attributes, such as Quantity of Mesophilic Aerobic and Facultative Anaerobic Microorganisms (QMAFAnM), yeasts and molds were determined Pasteur method. The acid and peroxide values were determined by the titration method.

Results and discussion. The oxygen complete removal time in the packed sample is reduced with reduce volume from which oxygen is removed. From the minimum oxygen content renewal dynamics in the packaged samples it can be seen that the ability to recover MAP only works when the packaging were opened once. The QMAFAnM of unpacking samples was $4,5 \times 10^{2}$ $\mathrm{cfu} / \mathrm{g}$. On the $8^{\text {th }}$ day of storage QMAFAnM for samples with chinese oxygen scavengers and control stored at $0+6{ }^{\circ} \mathrm{C}$ were not significantly different $\left(5,0 \times 10^{3} \mathrm{cfu} / \mathrm{g}\right.$ and $6,5 \times 10^{3} \mathrm{cfu} / \mathrm{g}$, respectively) and were was significantly lower than the sample with ukrainian oxygen scavenger $\left(1,9 \times 10^{4} \mathrm{cfu} / \mathrm{g}\right)$. On the $13^{\text {th }}$ day of storage, QMAFAnM for sample 3 were lower than sample $2\left(1,2 \times 10^{4} \mathrm{cfu} / \mathrm{g}\right.$ and $6,9 \times 10^{4} \mathrm{cfu} / \mathrm{g}$, respectively). At the same time, this parameter was much higher for control. Sample 2 and Sample 3 demonstrated stable meaning of moulds during entire research $(<10 \mathrm{cfu} / \mathrm{g})$ and were lower than counts from control $\left(3,0 \times 10^{1} \mathrm{cfu} / \mathrm{g}\right.$ on $13^{\text {th }}$ day). All samples demonstrated yeasts increase during storage and no significant differences between were observed compared to control $\left(7,0 \times 10^{1}-4,8 \times 10^{2}\right.$ $\mathrm{cfu} / \mathrm{g}$ and $5,0 \times 10^{2} \mathrm{cfu} / \mathrm{g}$ respectively). The initial acid value for unpacking sausages on 1 storage day was $1,41 \mathrm{mg} \mathrm{KOH} / \mathrm{g}$. On the $13^{\text {th }}$ day of storage the sausages packed with oxygen scavengers stored at $0+6{ }^{\circ} \mathrm{C}$ showed the slightest increase compared to the control $(3,57-3,76 \mathrm{mg} \mathrm{KOH} / \mathrm{g}$ and $3,98 \mathrm{mg}$ $\mathrm{KOH} / \mathrm{g}$ respectively). Peroxide value for samples 2 and $3 \mathrm{did}$ not differ after $13 \mathrm{~d}$ of storage, but were significantly lower than control $(3,14 \quad 1 / 2 \mathrm{Ommol} / \mathrm{kg}, \quad 3,36 \quad 1 / 2 \mathrm{Ommol} / \mathrm{kg}$ and 4,05 $1 / 2 \mathrm{Ommol} / \mathrm{kg}$ ).

Conclusions. Packaging with oxygen scavenger slows down the microbiological spoilage and oxidation processes for cooked sausages compared to the control. This allows recommend the use of oxygen scavenger for the cooked sausages packaging. 


\section{Introduction}

The selection of the packaging solution plays an important role: it has to guarantee the safety of the product during storage.

The object of the present research was to study the ukrainian and chinese oxygen scavengers effect on the microbiological stability and oxidation stability of a cooked sausages during storage.

Active packaging application for food products. Packaging of food extends beyond the original function of product protection and provides many functions for and about the packaged product. Packaging and packaging-related product traits influence purchase intentions and decisions by consumers [1,2]. The major packaging options are airpermeable, vacuum, and modified atmosphere (MAP) with low levels of oxygen or high levels of oxygen $[3,4]$.

Active packaging is a novel technology designed to incorporate components in the packaging material that release substances to the food or to the environment surrounding the food in order to extend shelf-life. The protection or shelf life of the product in response to interactions of the product, package and environment are often the functions of active packaging technologies, but other functions may also be employed [5].

The development of a whole range of active packaging systems, some of which may have applications in both new and existing food products, is fairly new.

Active packaging types were categorized into moisture absorbers, antimicrobial packaging, $\mathrm{CO}_{2}$ emitters, $\mathrm{O}_{2}$ scavengers, antioxidant, and other groups [6].

EU regulations (№ 1935/2004 and 450/2009) give specific rules on new types of materials and compounds to actively maintain or improve condition of the food, encompassing antioxidant, preservative, and flavor components. The approaches for active packaging are to incorporate the active compounds into a sachet for use with the packaging, to disperse active compounds, usually of nanometric size, into the polymer matrix or to imbed the inorganic particles into the package surface for controlled release. The EU guidance also includes the function of package absorption of chemicals from the food or package environment $[7,8]$.

High levels of oxygen present in food packages may facilitate microbial growth, off flavours and off odours development, colour changes and nutritional losses thereby causing significant reduction in the shelf life of foods. Oxygen absorbing systems provide an alternative to vacuum and gas flushing technologies as a means of improving product quality and shelf life [9].

To reduce the access of oxygen, foods are packaged with barrier materials and the headspace of packagings is flushed with nitrogen or nitrogen/carbon dioxide mixtures [10].

However, residual oxygen can remain in the headspace, it can permeate from the environment into the packaging or it is gotten into packagings as solved oxygen in food [11]. A strategy to reduce the oxygen permeability of plastic packagings and to absorb oxygen from packaged food and from packaging headspace is the application of oxygen scavengers. Oxygen scavengers remove oxygen from the inner package environment and thus, in turn, from the food product itself through partial pressure actions.

Although oxygen sensitive foods can be packaged accordingly using MAP or_vacuum packaging, such techniques do not always facilitate complete removal of oxygen. Using an oxygen scavenger, which absorbs the residual oxygen after packaging, quality changes in oxygen sensitive foods can often be minimised [12]. 
The oxygen scavenging component of a package can take the form of a sachet, label, film (incorporation of scavenging agent into the packaging film), card, closure liner or concentrate [13]. Absorbent pads may absorb liquids or gases and be impregnated with silver, copper, or copper oxide nanoparticles [14].

Oxygen scavengers are most commonly iron or ferrous oxide fine powders, although ascorbic acid, sulphites, catechol, ligands, and enzymes like glucose oxidase may also be used $[15,16,17,18]$.

The most commonly used oxygen scavenger for commercial purposes are iron powder satchets. These scavengers are based on the principle of oxidation in presence of moisture or lewis acids like $\mathrm{FeCl}_{3}[19]$.

\section{Materials and methods}

The present study focused on the monitoring of Quantity of Mesophilic Aerobic and Facultative Anaerobic Microorganisms (QMAFAnM), yeasts, molds, acid value and peroxide value in cooked sausages.

\section{Experimental design}

Studies of oxygen scavenger were conducted to determine their impact on the final product during storage.

Industrial production «Austrian» cooked sausages of the first chop were investigated. Ingredients: meat $65 \%$ (pork, chicken meat), animal protein stabilizer, mechanically deboned poultry, whey powder, potato starch, egg powder, water, salt, spices and their extracts (nutmeg, black pepper, garlic, juniper, coriander, chilli, bay leaf), flavor enhancer, color retainer. Shelf life at temperature $0+6^{\circ} \mathrm{C}$, and relative humidity $75 \%-78 \%-3$ days in the case of open packaging.

«Austrian» sausages were packaged with the following systems:

Sample 1 - control sample packed without oxygen scavengers, stored at $0+6{ }^{\circ} \mathrm{C}$,

Sample 2 - sausage packed with ukrainian oxygen scavengers stored at $0+6^{\circ} \mathrm{C}$,

Sample 3 - sausage packed with chinese oxygen scavengers stored at $0+6{ }^{\circ} \mathrm{C}$,

Sample 4 - sausage packed with chinese oxygen scavengers stored at $+24+26{ }^{\circ} \mathrm{C}$.

The sausages were stored at $0+6^{\circ} \mathrm{C}$ and $+24+26^{\circ} \mathrm{C}$ for 13 days. Analysis of unpacked cooked sausages was carried out on day 1, packed cooked sausages - on days 8 and 13 of storage.

\section{Determination of the microbiological attributes}

$10 \mathrm{~g}$ of each sample were aseptically placed into a stomacher bag. Afterward, $90 \mathrm{~cm}^{3}$ of Peptone Saline Solution (PSS) was added and homogenized using a stomacher for $60 \mathrm{~s}$ at room temperature. Serial 10 -fold dilutions were prepared by diluting $1 \mathrm{~cm}^{3}$ of homogenate in $9 \mathrm{~cm}^{3}$ of PSS [20].

Serial decimal dilutions were inoculated $\left(1 \mathrm{~cm}^{3}\right)$ onto nutrient agar for QMAFAnM and onto Sabouraud agar for yeasts and molds. Plates were incubated at $30 \pm 1{ }^{\circ} \mathrm{C}$ for $72 \mathrm{~h}$ for QMAFAnM and $24 \pm 1{ }^{\circ} \mathrm{C}$ for $120 \mathrm{~h}$ for yeasts and molds.

After incubation, two plates with nutrient agar and Sabouraud agar for each sampling point were counted. Results were expressed as a number of colony forming units per gram (cfu/g). All plates were examined visually for typical colony types and morphological characteristics that were associated with each growth medium. 


\section{Determination of the lipid oxidation}

The method for determining the peroxide value is based on the reaction of the fat oxidation (peroxides and hydroperoxides) primary products interaction with potassium iodide in an acidic medium, followed by titration with a sodium thiosulfate solution and quantitative determination of the released iodine [21].

The method for determining the acid value is based on free fatty acids titration with a potassium hydroxide solution.

\section{Results and discussion}

\section{Oxygen scavengers caracteristics}

Oxygen scavengers active component is the iron activated form, which is standardized for its reactivity with oxygen in the moisture presence.

The oxygen scavenger functional ability to remove oxygen present in packaged sausages was examined. This ability characterized the oxygen scavenger effectiveness to modify the MAP by oxygen content in the system.

The decrease of oxygen concentration dynamics in different volumes $\left(0,001 \mathrm{~m}^{3}\right.$ and $0,002 \mathrm{~m}^{3}$ ) was investigated.

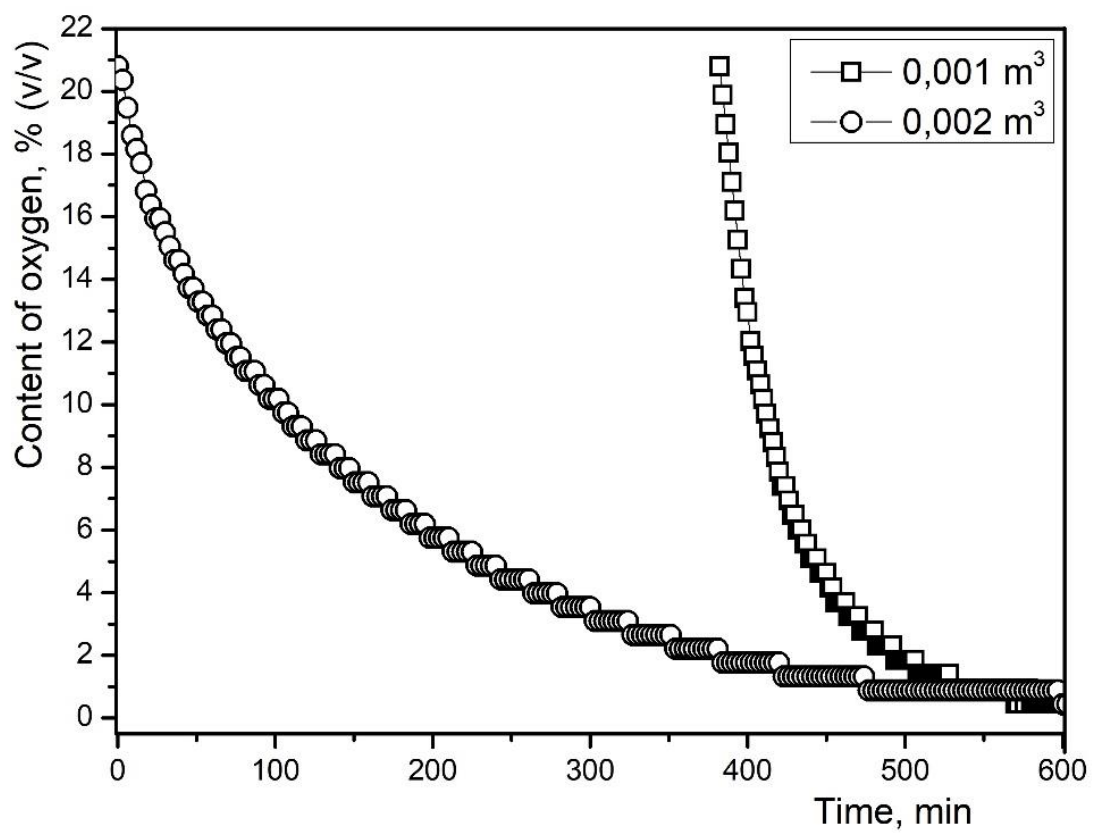

Figure 1. Oxygen concentration dynamics in different volumes with oxygen scavenger

Figure 1 shows that the oxygen complete removal time in the packed sample is reduced with reduce the volume from which oxygen is removed. In this case, this dependence is exponential. The oxygen concentration dynamics in this study is in accordance with previous studies [22]. 
In order to ensure the viability of the active packaging elements in the process of technological use, its ability to maximum oxygen removal with package partial depressurization was studied.

The studies were performed by measuring the oxygen concentration in a closed volume with the container subsequent opening.

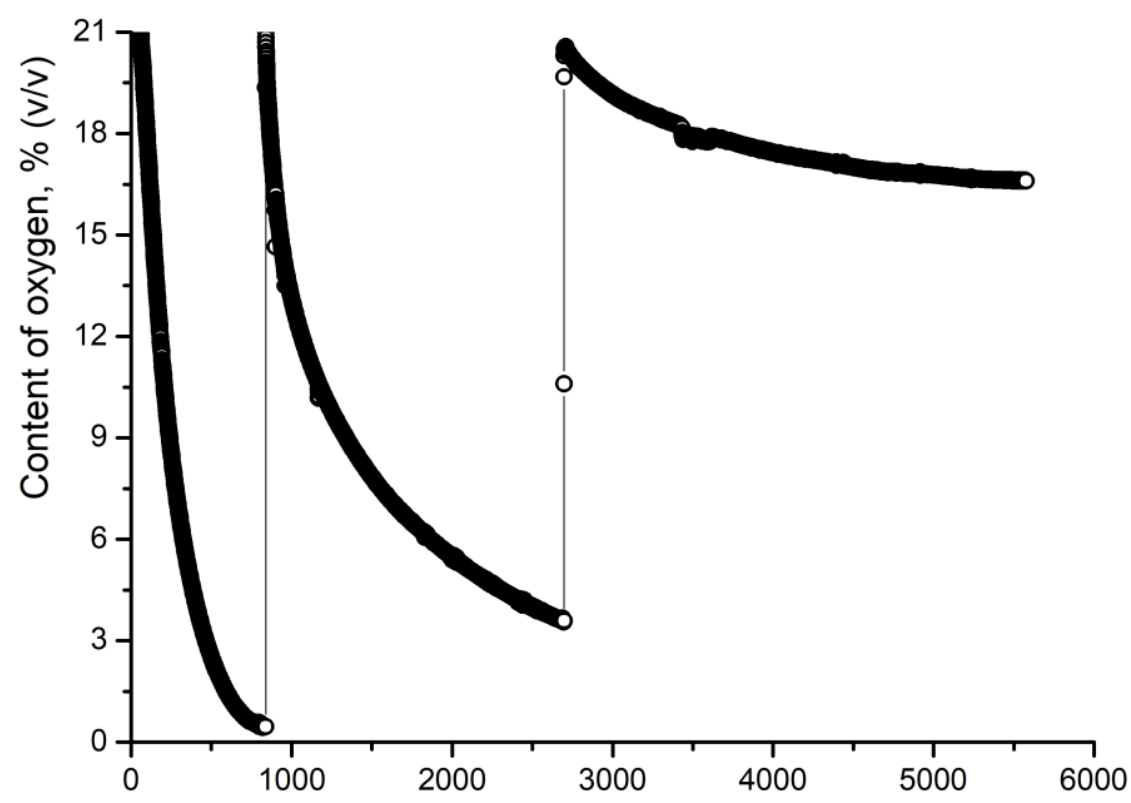

Figure 2. The action of ukrainian oxygen scavenger to restore MAP with package depressurization

From the minimum oxygen content renewal dynamics in the packaged samples shown in Figure 2, it can be seen that the ability to recover MAP only works when the packaging were opened once.

Figure 3 presents the oxygen removal kinetics in packaged sausages samples. The experimental packaging system contained the sausages sample with the oxygen scavenger had a $0,0005 \mathrm{~m}^{3}$ volume.

The MAP modification kinetics of packaged sample (Figure 3) was consistent with the oxygen removal kinetics in a pressurization volume, which allows us to state that the sausages storage process is regulated.

\section{Cooked sausage samples microbiological attributes}

The changes in the cooked sausage QMAFAnM during storage are shown in Figure 4. 


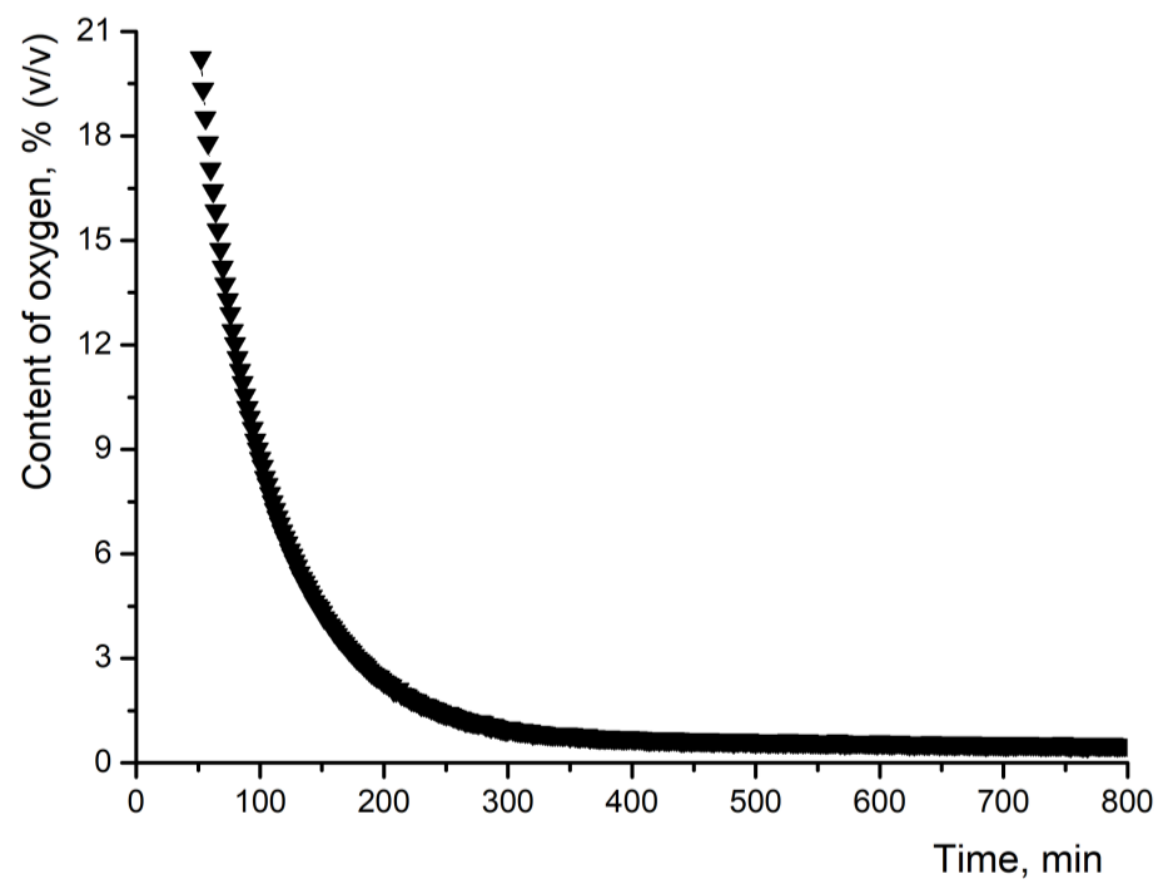

Figure 3. Oxygen removal kinetics in packaged sausages sample with oxygen scavenger

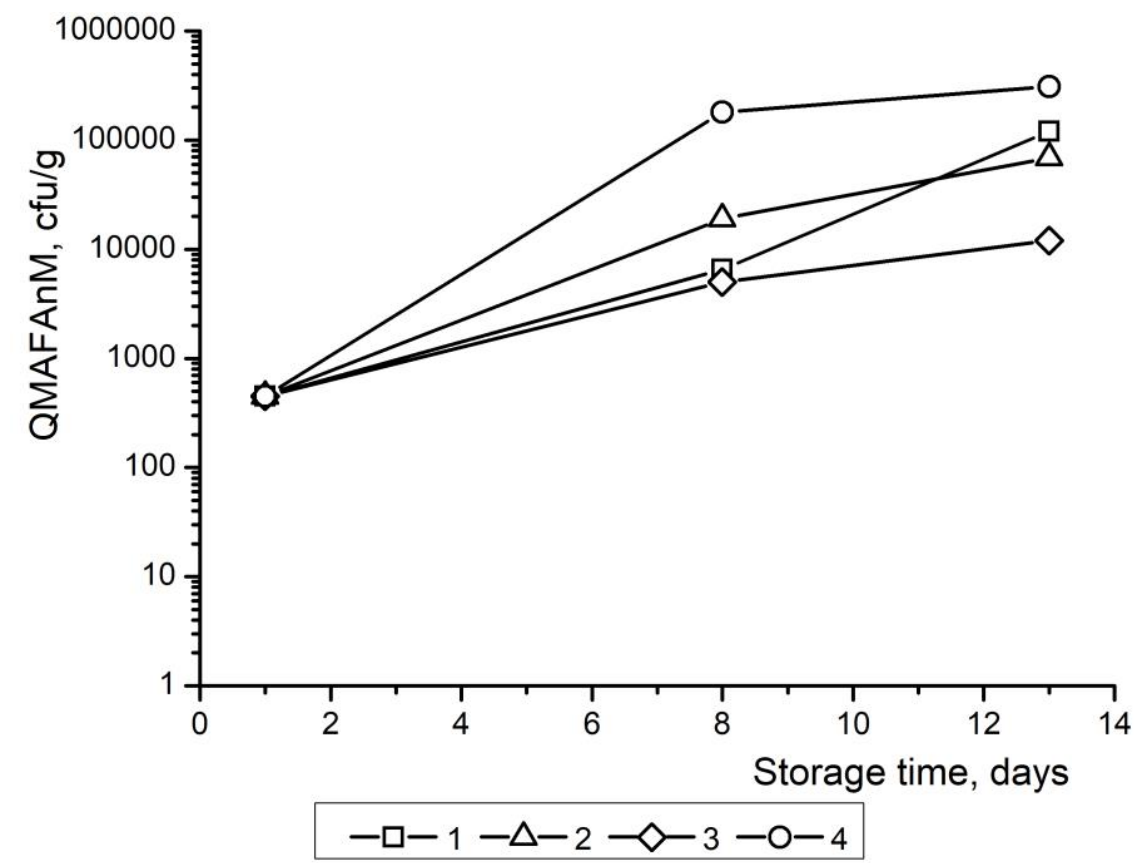

Figure 4. QMAFAnM changes in cooked sausage with different packaging d uring 13 days of storage 
The QMAFAnM of unpacking samples was $4,5 \times 10^{2} \mathrm{cfu} / \mathrm{g}$.

On the $8^{\text {th }}$ day of storage QMAFAnM for samples with chinese oxygen scavengers and control stored at $0+6{ }^{\circ} \mathrm{C}$ were not significantly different $\left(5,0 \times 10^{3} \mathrm{cfu} / \mathrm{g}\right.$ and $6,5 \times 10^{3} \mathrm{cfu} / \mathrm{g}$, respectively) and were was significantly lower than the sample with ukrainian oxygen scavenger $\left(1,9 \times 10^{4} \mathrm{cfu} / \mathrm{g}\right)$. The maximum value was for sample $4-1,8 \times 10^{5} \mathrm{cfu} / \mathrm{g}$.

On the $13^{\text {th }}$ day of storage, QMAFAnM for sample 3 were lower than sample $2\left(1,2 \times 10^{4}\right.$ $\mathrm{cfu} / \mathrm{g}$ and $6,9 \times 10^{4} \mathrm{cfu} / \mathrm{g}$, respectively). At the same time, this parameter was much higher for control and sample with oxygen scavenger stored at $+24+26^{\circ} \mathrm{C}$.

The initial population of moulds for unpacked sample was $<10 \mathrm{cfu} / \mathrm{g}$, initial population of yeasts for unpacked sample was $10 \mathrm{cfu} / \mathrm{g}$.

The results of further studies are presented in Table 1.

Changes of moulds in packed cooked sausage during storage

Table 1

\begin{tabular}{|l|c|c|c|c|}
\hline \multirow{2}{*}{ Days of storage } & \multicolumn{4}{|c|}{ Moulds, cfu/g } \\
\cline { 2 - 5 } & Sample 1 & Sample 2 & Sample 3 & Sample 4 \\
\hline 8 & $2,0 \times 10^{1}$ & $<10$ & $<10$ & $5,0 \times 10^{1}$ \\
\hline 13 & $3,0 \times 10^{1}$ & $<10$ & $<10$ & $5,0 \times 10^{1}$ \\
\hline
\end{tabular}

Sample 2 and Sample 3 demonstrated stable meaning of moulds during entire research and were lower than counts from control. It can be concluded that use of oxygen scavengers effective for the inhibition of moulds.

The development of the yeasts for the samples is shown in Table 2.

Changes of yeasts in packed cooked sausage during storage

Table 2

\begin{tabular}{|c|c|c|c|c|}
\hline \multirow{2}{*}{$\begin{array}{c}\text { Days } \\
\text { of storage }\end{array}$} & \multicolumn{4}{|c|}{ Yeasts, cfu/g } \\
\cline { 2 - 5 } & Sample 1 & Sample 2 & Sample 3 & Sample 4 \\
\hline 8 & $3,3 \times 10^{2}$ & $2,0 \times 10^{2}$ & $3,0 \times 10^{2}$ & $3,0 \times 10^{1}$ \\
\hline 13 & $5,0 \times 10^{2}$ & $4,6 \times 10^{2}$ & $4,8 \times 10^{2}$ & $7,0 \times 10^{1}$ \\
\hline
\end{tabular}

All samples demonstrated yeasts increase during storage and no significant differences between were observed compared to control. So use of oxygen scavengers did not inhibit yeasts.

Oxygen is responsible for oxidation of food constituents and proliferation of aerobic bacteria and moulds resulting in quality losses due to changes in flavour, colour, texture and nutritive value, and therefore in a reduction of meat shelf life [23]. Those results clearly demonstrated the inhibitory effect on microbial growth of oxygen scavengers in accordance with previous reports [24].

\section{Cooked sausage samples acid value and peroxide value}

The kinetics of fat oxidation during the sausages storage was characterized by acid and peroxide values. The depth of the fat hydrolytic changes was determined use an acid value that shows the amount of free fatty acids formed during the fat hydrolysis. 
The initial acid value for unpacking sausages on 1 storage day was 1,41 mg KOH/g. The results of further studies are presented in Table 3.

Changes of acid value in cooked sausage during storage

Table 3

\begin{tabular}{|c|c|c|c|c|}
\hline \multirow{2}{*}{$\begin{array}{c}\text { Days } \\
\text { of storage }\end{array}$} & \multicolumn{4}{|c|}{ Acid value, mg KOH/g } \\
\cline { 2 - 5 } & Sample 1 & Sample 2 & Sample 3 & Sample 4 \\
\hline 8 & 2,91 & 3,11 & 3,09 & 4,11 \\
\hline 13 & 3,98 & 3,57 & 3,76 & 4,46 \\
\hline
\end{tabular}

The increase of acid value rate for the samples packed with oxygen scavenger stored at $+24+26{ }^{\circ} \mathrm{C}$ was highest. At the same time, the sausages packed with oxygen scavengers stored at $0+6{ }^{\circ} \mathrm{C}$ acid value dynamics for 13 days of storage showed the slightest increase compared to the control, indicating the inhibition of the hydrolysis process.

To determine the primary oxidation products of sausages was evaluated peroxide value, with which you can determine the damage degree of fat, which affects the product shelf life.

For unpackaged sausages, the peroxide value was $1,981 / 2 \mathrm{Ommol} / \mathrm{kg}$ immediately.

The results of further studies are presented in Table 4.

Table 4

Changes of peroxide value in cooked sausage during storage

\begin{tabular}{|c|c|c|c|c|}
\hline \multirow{2}{*}{$\begin{array}{c}\text { Days } \\
\text { of storage }\end{array}$} & \multicolumn{4}{|c|}{ Peroxide value, 1/20mmol/kg } \\
\cline { 2 - 5 } & Sample 1 & Sample 2 & Sample 3 & Sample 4 \\
\hline 8 & 2,42 & 2,58 & 2,34 & 3,41 \\
\hline 13 & 4,05 & 3,14 & 3,36 & 4,72 \\
\hline
\end{tabular}

The results obtained show that peroxide value increased more intensively for the samples packed with oxygen scavenger stored at $+24+26{ }^{\circ} \mathrm{C}$. At the same time the oxygen scavengers use in samples stored at $0+6{ }^{\circ} \mathrm{C}$ slowed the oxidation processes.

These results are in line with the study of L. Martinez et al. in which samples with $\mathrm{O}_{2}$ scavenger had the lowest values of pork sausages lipid oxidation and led to extension of shelf life due to low oxidation rates [25].

\section{Conclusions}

It has been found that with the reduced volume, the time of oxygen complete removal in the packed sample is reduced. In this case, this dependence is exponential.

The MAP modification kinetics of packaged sample was consistent with the oxygen removal kinetics in a pressurization volume, which allows us to state that the sausages storage process is regulated.

The QMAFAnM samples packed using oxygen scavenger stored at $0+6{ }^{\circ} \mathrm{C}$ increased more slowly compared to the control regardless of the origin of the scavenger. These samples also showed stable values of molds and yeasts at all control points. 
Packaging with oxygen scavenger slows down the oxidation processes for cooked sausages compared to the control.

This allows recommend the use of oxygen scavenger for the cooked sausages packaging.

At the same time, the use of oxygen scavengers does not inhibit the development of yeast for cooked sausages, which needs further investigation.

\section{References}

1. Verbeke W., De Smet S., Vackier I., Van Oeckel M. J., Warnats N., Van Kenhove P., (2005), Role of intrinsic search cues in the formation of consumer preferences and choice for pork chops, Meat Science, 69(2), pp. 343-354.

2. Grobbel J. P., Dikeman M. E., Hunt M.C., Milliken G. A., (2008), Effects of packaging atmospheres on beef instrumental tenderness, fresh color stability, and internal cooked color, Journal of Animal Science, 86, pp. 1191-1199.

3. McMillin K. W. (2008), Where is MAP going? A review and future potential of modified atmosphere packaging for meat, Meat Science, 80, pp. 43-65.

4. Pasichnyj VM, Ukrainec AI, Khrapachov OV, Marynin AI (2017), Perspektyvy vykorystannja pakuval'nyh materialiv dlja termichnoi'obrobky m'jasa ta m'jasoproduktiv, Tekhnika, energhetyka, transport APK, 2(97), pp. 71-75.

5. Yam K. L., Takhistov P. T., Miltz J., (2005), Intelligent packaging: Concepts and applications, Journal of Food Science, 70(1), pp. 1-10.

6. Realini C. E. Marcos B. (2014), Active and intelligent packaging systems for a modern society, Meat Science, 98, pp. 404-419.

7. Fang Z., Zhao Y., WarnerR. D., Johnson S. K., (2017), Active and intelligent packaging in meat industry, Trends in Food Science Technology, 61, pp. 60-71.

8. de Kruijf N., van Beest M., Rijk R., Sipiläinen-Malm Losada P. P., De Meulenaer B., (2002), Active and intelligent packaging: applications and regulatory aspects, Food Additives and Contaminants, 19, Supplement, pp. 144-162.

9. Ozdemir M., Floros J. D. (2004), Active food packaging technologies, Critical Reviews in Food Science and Nutrition, 44(3), pp. 185-193.

10. Lange J., Wyser Y. (2003), Recent innovations in barrier technologies for plastic packaging-a review, Packaging Technology and Science, 16(4), pp. 149-158.

11. Chaix E., Guillaume C., Guillard V. (2014), Oxygen and carbon dioxide solubility and diffusivity in solid food matrices: A review of past and current knowledge, Comprehensive Reviews in Food Science and Food Safety, 13(3), pp. 261-286.

12. Vermeiren L., Devlieghere F., Van Beest M., de Kruijf N., Debevere J. (1999), Developments in the active packaging of foods, Trends in Food Science and Technology, 10, pp. 77-86.

13. Suppakul P., Miltz J., Sonneveld K., Bigger S.W. (2003), Active packaging technologies with an emphasis on antimicrobial packaging and its applications, Journal of Food Science, 68, pp. 408-420.

14. Otoni C. G., Espitia P. J. P., Avena-Bustillos R. J., McHugh T. H., (2016), Trends in antimicrobial food packaging systems: Emitting sachets and absorbent pads, Food Research International, 83, pp. 60-73.

15. Brody A. L., Bugusu B., Han J. H., Sand C. K., McHugh T. H. (2008), Innovative food packaging solutions, Journal of Food Science, 73, pp. 107-116. 
16. Yu J., Liu R. Y. F., Poon B., Nazarenko S., Koloski T., Vargo T., (2004), Polymers with palladium nanoparticles as active membrane materials, Journal of Applied Polymer Science, 92(2), pp. 749-756.

17. Hamilton R. J., Kalu C., Prisk E., Padley F. B., Pierce H. (1997), Chemistry of free radicals in lipids, Food Chemistry, 60(2), pp. 193-199.

18. Sangatash M. M., NiazmandR., Jamab M. S., Modaressi A. S., (2016), Development of antioxidant active films containing sodium ascorbate (SA) and ethylene vinyl alcohol (EVOH) to extend the shelf life of peanut, Journal of Food Science Technology, 53(4), pp. 1766-1783.

19. Cruz R. S., Soares N. D. F. F., Andrade N. J. D. (2006), Evaluation of oxygen absorber on antimicrobial preservation of lasagna-type fresh pasta under vacuum packed, Ciencia E Agrotecnologia, 30(6), pp. 1135-1138.

20. Ukrainets A., Pasichniy V., Zheludenko Yu., Zadkova S. (2016), Oleoresins effect on cooked poultry sausages microbiological stability, Ukrainian Food Journal, 5 (1), pp. 124-134.

21. Bozhko N., Tischenko V., Baidak L., Pasichnyi V. (2018), Evaluation of rosemary extract effectiveness in the technology of meat-containing sausages with duck meat Ukrainian Food Journal, 7 (1), pp. 54-64.

22. Hutter S., Ruegg N., Yildirim S. (2016), Use of palladium based oxygen scavenger to prevent discoloration of ham, Food Packaging and Shelf Life, 8, pp. 56-62.

23. Brody A.L., Strupinsky E.R., Kline L.R. (2001), Active packaging for food applications, Technomic Publishing Company, Lancaster.

24. Kerry J.P., O'Grady M.N., Hogan S.A. (2006), Past, current and potential utilisation of active and intelligent packaging systems for meat and muscle-based products: A review, Meat Science, 74, pp. 113-130.

25. Martinez L., Djenane D., Cilla I., Beltran J. A., Roncales P., (2006), Effect of varying oxygen concentrations on the shelf-life of fresh pork sausages packaged in modified atmosphere, Food Chemistry, 94, pp. 219-225. 